Review

\title{
Assessing the Mechanism of Fluoxetine-Mediated CYP2D6 Inhibition
}

\author{
Malavika Deodhar ${ }^{1} \mathbb{D}$, Sweilem B. Al Rihani ${ }^{1} \mathbb{D}$, Lucy Darakjian ${ }^{1}$, Jacques Turgeon ${ }^{1,2}$ and \\ Veronique Michaud 1,2,*
}

1 Precision Pharmacotherapy Research and Development Institute, Tabula Rasa Health Care, Lake Nona, Orlando, FL 32827, USA; mdeodhar@trhc.com (M.D.); srihani@trhc.com (S.B.A.R.); ldarakjian@trhc.com (L.D.); jturgeon@trhc.com (J.T.)

2 Faculty of pharmacy, Université de Montréal, Montréal, QC H3C 3J7, Canada; jacques.turgeon@umontreal.ca

* Correspondence: vmichaud@trhc.com or v.michaud@umontreal.ca

Citation: Deodhar, M.; Rihani, S.B.A.; Darakjian, L.; Turgeon, J.; Michaud, V. Assessing the Mechanism of Fluoxetine-Mediated CYP2D6 Inhibition. Pharmaceutics 2021, 13, 148. https://doi.org/10.3390/ pharmaceutics13020148

Academic Editor: Im-Sook Song

Received: 2 December 2020

Accepted: 18 January 2021

Published: 23 January 2021

Publisher's Note: MDPI stays neutral with regard to jurisdictional claims in published maps and institutional affiliations.

Copyright: (c) 2021 by the authors. Licensee MDPI, Basel, Switzerland. This article is an open access article distributed under the terms and conditions of the Creative Commons Attribution (CC BY) license (https:// creativecommons.org/licenses/by/ $4.0 /)$.

\begin{abstract}
Fluoxetine is still one of the most widely used antidepressants in the world. The drug is extensively metabolized by several cytochrome P450 (CYP450) enzymes and subjected to a myriad of CYP450-mediated drug interactions. In a multidrug regimen, preemptive mitigation of drugdrug interactions requires knowledge of fluoxetine actions on these CYP450 enzymes. The major metabolic pathway of fluoxetine leading to the formation of its active metabolite, norfluoxetine, is mediated by CYP2D6. Fluoxetine and norfluoxetine are strong affinity substrates of CYP2D6 and can inhibit, potentially through various mechanisms, the metabolism of other sensitive CYP2D6 substrates. Remarkably, fluoxetine-mediated CYP2D6 inhibition subsides long after fluoxetine first passes through the liver and even remains long after the discontinuation of the drug. Herein, we review pharmacokinetic and pharmacogenetic information to help us understand the mechanisms underlying the prolonged inhibition of CYP2D6 following fluoxetine administration. We propose that long-term inhibition of CYP2D6 is likely a result of competitive inhibition. This is due to strong affinity binding of fluoxetine and norfluoxetine to the enzyme and unbound fluoxetine and norfluoxetine levels circulating in the blood for a long period of time because of their long elimination half-life. Additionally, we describe that fluoxetine is a CYP2C9 substrate and a mechanism-based inhibitor of CYP2C19.
\end{abstract}

Keywords: fluoxetine; norfluoxetine; drug interactions; CYP2D6; metabolism; competitive inhibition; mechanism-based inhibition

\section{Introduction}

Patients presenting with several chronic conditions such as psychiatric disorders, cardiovascular disorders, diabetes, and rheumatoid arthritis often require multiple therapeutic approaches, including the use of numerous drugs, to achieve clinical benefits and experience favorable outcomes [1-4]. The co-administration of multiple drugs required to treat complex conditions and associated comorbidities can lead to major pharmacokinetic and/or pharmacodynamic drug-drug interactions (DDIs) [5-7]. These circumstances also impact drug safety, adherence, and efficacy [8,9]. The cytochrome P450 (CYP450) monooxygenase superfamily of enzymes is commonly involved in the metabolic processes regulating drug disposition [10,11]. CYP450 enzymes are responsible for metabolizing about $75 \%$ of all prescribed medications and contribute greatly to DDIs in patients with polypharmacy [12].

In recent years, an increased incidence of depression with an associated increase in the use of antidepressants has been noted [13-16]. Fluoxetine is still one of the most widely used antidepressants worldwide, with 21,913,276 prescriptions filled in the United States in 2017 [17]. Fluoxetine is a selective serotonin reuptake inhibitor (SSRI) indicated for the treatment of psychiatric conditions such as major depressive disorder, obsessive compulsive 
disorder, bulimia nervosa, and panic disorder [18]. Eli Lilly received patent protection for fluoxetine in 1974, and the drug was approved in the USA for medical use in 1987 [19]. It is considered one of the most stimulating SSRIs; this property, along with its a rather favorable side-effect profile, offers clinical advantages $[20,21]$. It is well recognized that CYP2D6 is the major CYP450 enzyme involved in the metabolism of fluoxetine [22]. CYP2D6 is also known to be involved in the metabolism of opioid painkillers, such as tramadol and codeine, beta-blockers, class I antiarrhythmic drugs, first-generation H1-antagonists, tricyclic antidepressants, and other small amine-containing compounds [23-25]. Concomitant use of fluoxetine with any of these agents poses a risk for potential DDIs leading to therapeutic failure or adverse reactions. More importantly, inhibition of CYP2D6 by fluoxetine has been reported to subside long after fluoxetine first passes through the liver and even lingers long after the discontinuation of the drug [26,27]. In this review, we aim to shed light on the mechanisms of fluoxetine-mediated CYP2D6 inhibition and its interactions with other CYP450s (CYP2C9, CYP2C19 and CYP3A4). We discuss whether fluoxetine is either a perpetrator or victim drug and whether fluoxetine interactions with various CYP450s may lead to reversible or irreversible inhibition.

\section{Mechanisms of CYP450 Inhibition}

Drug interactions associated with CYP450 inhibition are classified as reversible (i.e., competitive or noncompetitive) or irreversible (i.e., mechanism-based inhibition) [28]. Firstly, competitive inhibition occurs when two substrates, present in the surrounding of the enzyme at the same time, compete for the same active site. Whether a substrate is a perpetrator or a victim drug is a function of its respective affinity for the binding site, its concentration in the proximity of the enzyme, and the basal level of the enzyme activity [28]. Under conditions of competitive inhibition, separating the time of administration has often been a successful interaction-mitigating strategy, since in this type of inhibition, the basal enzyme (protein) level is not impacted [28]. A noncompetitive inhibitor usually has no structural resemblance with the substrate of an enzyme; the noncompetitive inhibitor generally binds to an allosteric site leading to a conformational change, rendering the active site unavailable for substrate binding [29]. Lastly, mechanism-based inhibition is a subset of time-dependent inhibition, which can occur when a substrate forms a reactive metabolite or, in rare cases, a substrate binds so tightly to the enzyme acting as a suicide inhibitor, leading to an irreversible reduction of enzymatic activity [28,30,31]. In cases of noncompetitive inhibition and mechanism-based inhibition, separating administration time of the perpetrator and victim drugs cannot prevent the interaction [28].

\section{Fluoxetine Metabolism}

Fluoxetine is extensively metabolized by various CYP450s such that only $\sim 2.5 \%$ of the administered dose is excreted unchanged in urine [32]. The $N$-demethylation of fluoxetine produces norfluoxetine, an active metabolite with potent serotonin selective reuptake inhibition (SSRI) activity [21]. Other metabolic pathways include glucuronidation and $O$-dealkylation converting fluoxetine into $p$-trifluoromethylphenol which subsequently is transformed into hippuric acid, a glycine conjugate [33-35]. Fluoxetine metabolism to norfluoxetine is stereoselective and involves CYP2D6, CYP2C9, and possibly CYP2C19 (Figure 1). In vivo in humans, it is evident that CYP2D6 plays a much greater role than any other enzyme [22,36]. Since fluoxetine remains under various conditions a possible substrate of all these enzymes, the likelihood of DDIs when co-administered with other drugs is real. However, the extent or significance of these interactions depends on whether fluoxetine acts as a victim drug or perpetrator drug at each of these enzymes.

CYP2D6 is mainly responsible for metabolizing both S- and R-fluoxetine to norfluoxetine corresponding enantiomers (intrinsic clearance, CLint $=2.24 \mathrm{uL} / \mathrm{min} / \mathrm{pmol}$ of CYP, and $2.91 \mathrm{uL} / \mathrm{min} / \mathrm{pmol}$ of CYP, respectively) [37]. However, the preferential metabolism of S-fluoxetine to S-norfluoxetine has been demonstrated in pharmacogenetic studies [38]. 


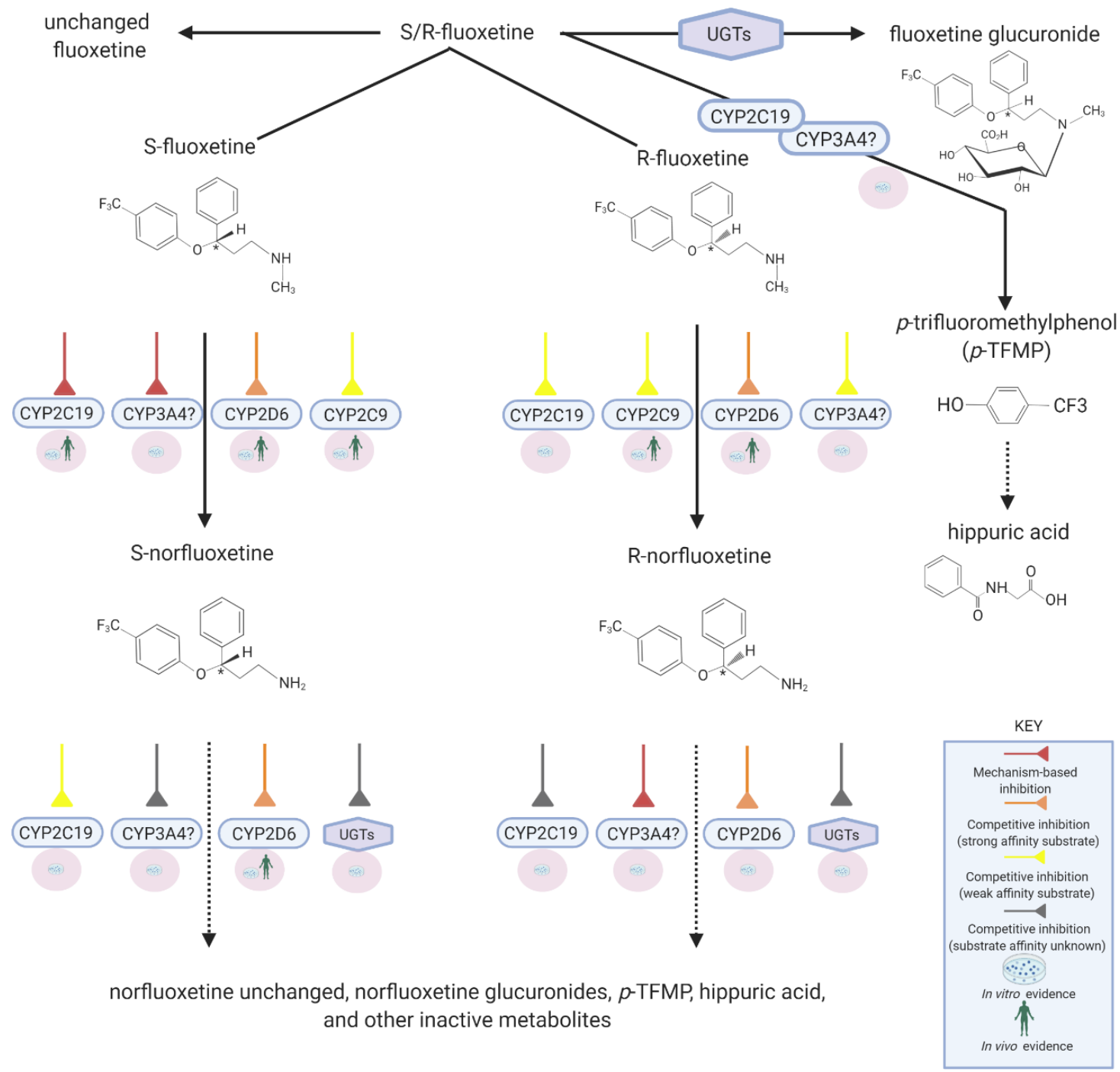

Figure 1. Disposition pathways of fluoxetine. Created with BioRender.com.

\section{Mechanism of CYP2D6 Inhibition by Fluoxetine}

S-Fluoxetine and S-norfluoxetine are both substrates and exhibit a high binding affinity to CYP2D6 (Ki $=68 \mathrm{nM}$ and $35 \mathrm{nM}$, respectively; $\mathrm{Ki}$ is reflective of the binding affinity of a potential inhibitor; the lower the $\mathrm{Ki}$, the higher the binding affinity is and smaller the amount of the drug needed in order to inhibit the activity of that enzyme) [39]. Thus, it is clear that competitive inhibition with sensitive CYP2D6 substrates is expected, and that fluoxetine and norfluoxetine will likely act as perpetrator drugs for several other CYP2D6 substrates. Accordingly, fluoxetine administration for 8 days is associated with a significant decrease in dextromethorphan clearance (a sensitive CYP2D6 substrate) and metabolism to dextrorphan: a 9- to 18-fold increase in the dextromethorphan/dextrorphan ratio [26,40]. Remarkedly, however, as is discussed further below (see Section 5), it took two to three weeks after discontinuation of fluoxetine for CYP2D6 activity to return back to baseline $[26,27]$. Understanding the exact mechanism of this prolonged inhibition of CYP2D6 activity poses certain challenges.

The first possibility is that prolonged CYP2D6 inhibition by fluoxetine might be due to noncompetitive inhibition. As a CYP2D6 substrate, fluoxetine must bind to the active site to be metabolized into norfluoxetine. By definition, pure noncompetitive inhibitors are not metabolized by the enzyme they inhibit [28]. Additionally, the 3D-conformational structure of noncompetitive inhibitors generally does not resemble that of enzyme substrates. Since 
fluoxetine is a CYP2D6 substrate, it appears not to meet some of the criteria of a pure noncompetitive inhibitor.

Second, fluoxetine could be a mixed CYP2D6 inhibitor, i.e., exhibiting both competitive and noncompetitive inhibition. This mechanism of inhibition gives rise to very potent enzyme inhibitors, often acting as perpetrator drugs with other sensitive substrates, while their pharmacokinetics are not affected by other inhibitors of the same enzyme [41]. In vitro studies showed that quinidine (a potent CYP2D6 inhibitor) was capable of inhibiting the $\mathrm{N}$-demethylation of fluoxetine with a magnitude similar to that observed with anti-CYP2D6 antibodies [37,42]. These data suggest that the probability of noncompetitive CYP2D6 inhibition by fluoxetine is rather unlikely but leave open the possibility for competitive inhibition.

Third, since fluoxetine is a CYP2D6 substrate, studies have been conducted to determine whether fluoxetine produces the time-dependent, mechanism-based inactivation of CYP2D6 [43]. Bertelsen et al. determined the time-dependent inhibitory potency of fluoxetine in human liver microsomes [43]. The $\mathrm{IC}_{50}$ for CYP2D6 inhibition by fluoxetine did not decrease with various times of pre-incubation periods to allow a potential reactive metabolite to be formed. These observations led to the conclusion that fluoxetine does not exhibit a time-dependent increase in its inhibitory potency and thus is not a mechanism-based inhibitor. Further evidence for the lack of noncompetitive and mechanism-based inhibition of CYP2D6 by fluoxetine is also obtained looking at results from pharmacogenetic studies. It is well known that poor metabolizers of CYP2D6 (carriers of two nonfunctional CYP2D6 alleles) exhibit decreased clearance characteristics of CYP2D6 probe substrates compared to normal CYP2D6 metabolizers (carriers of two functional CYP2D6 alleles) [44]. If noncompetitive or mechanism-based inhibition were to occur following administration of fluoxetine, the initial differences in fluoxetine pharmacokinetics observed between normal and poor metabolizers would disappear with time, as normal metabolizers would be phenoconverted to poor metabolizers due to the time-dependent decrease in CYP2D6 activity (phenoconversion being a phenomenon by which an genotype-predicted phenotype is transformed into another phenotype by factors such as drug interactions). In that sense, Fjordside et al. investigated the stereoselectivity of fluoxetine demethylation into norfluoxetine in patients on days 7,14 , and 23 following fluoxetine administration (20 mg) [38]. The plasma concentrations of fluoxetine and norfluoxetine enantiomers were measured in poor and normal metabolizers of CYP2D6. First, it was confirmed that CYP2D6-mediated demethylation of fluoxetine is stereoselective toward the S-enantiomer. Second, their results demonstrated a persistent difference between normal and poor metabolizers in the concentrations of S-fluoxetine and S-norfluoxetine even after 3 weeks of treatment [38]. Higher concentrations of S-fluoxetine and lower concentrations of S-norfluoxetine were observed in poor metabolizers compared to normal metabolizers. As indicated before, the persistent difference observed in fluoxetine pharmacokinetics between poor and normal metabolizers suggests a lack of CYP2D6 auto-inhibition via noncompetitive or mechanismbased inhibition. Scordo et al. also reported on the influence of CYP2D6 polymorphisms on fluoxetine steady-state pharmacokinetics: the median S-norfluoxetine/S-fluoxetine ratios were higher in homozygous compared to the heterozygous normal metabolizers for CYP2D6 [45]. Finally, a correlation between the fluoxetine/norfluoxetine ratio and CYP2D6 genotype (number of active CYP2D6 genes) was also reported in other clinical studies [36,46-48]. Overall, these findings support that (1) fluoxetine is a substrate of CYP2D6, (2) fluoxetine is not a noncompetitive inhibitor of CYP2D6, (3) CYP2D6 regulates the concentration of the S-enantiomer and the formation of S-norfluoxetine even after multiple doses, and (4) CYP2D6 inhibition by fluoxetine is not time-dependent, and therefore incompatible with mechanism-based inhibition. Thus, by eliminating the alternatives, it appears that fluoxetine is a strong affinity substrate of CYP2D6 and that the reduced CYP2D6 activity is likely mediated through competitive inhibition at the active site. However, the prolonged time-course of CYP2D6 inhibition which subsides even after stopping fluoxetine 
administration requires further investigation, since it is not commonly encountered when dealing with competitive inhibitors.

\section{Time Course of CYP2D6 Inhibition}

Conceptually, separating the time of administration between two competing substrates, such that their maximum concentrations in the liver or plasma do not overlap, is a meaningful way to mitigate DDIs caused by competitive inhibition. For most drugs, CYP2D6 inhibition is observed following drug absorption during the hepatic first pass phase (CYP2D6 is not expressed in the intestinal wall) since drug concentrations in the portal vein (which irrigates perilobular hepatocytes) are much higher than concentrations observed after peak plasma concentrations when drugs return to the liver via the hepatic artery. Generally, the ratio of drug concentrations observed in the portal vein during the absorption phase to that measured in the hepatic artery after the peak plasma concentration (when the absorption phase is almost completed) is very large (likely in the range of 100 to 1000). This is why separating the time of administration of two substrates that compete for the same enzyme circumvents competitive inhibition between these two substrates. However, as mentioned previously, in the case of fluoxetine, a prolonged CYP2D6 inhibition over two to three weeks was observed when dextromethorphan was used as a probe substrate [26,27]. Other reports have suggested that these prolonged effects may advantage fluoxetine over other SSRIs in avoiding withdrawal syndromes [49,50]. Significant DDIs have also been reported between fluoxetine and tricyclic antidepressants, several of them also being CYP2D6 substrates [51]. Desipramine (50 mg) mean plasma concentrations were increased 4.4-fold when co-administered with $20 \mathrm{mg}$ fluoxetine for 20 days [52]. Twentyone days post-discontinuation of fluoxetine, mean plasma concentrations of desipramine still remained 2.4-fold higher than baseline, demonstrating the long-term impact of fluoxetine administration on other CYP2D6 substrates [52]. It is established that both fluoxetine and norfluoxetine have very long half-lives of 4-6 days and 4-16 days, respectively [18]. Additionally, it has been reported that during chronic dosing, the terminal half-life of fluoxetine and norfluoxetine might increase to become slightly longer (8 and 19.3 days, respectively) [53]. Some particular characteristics may contribute to the prolonged effects of fluoxetine administration on CYP2D6. Persistent high concentrations of unbound fluoxetine and norfluoxetine in plasma are one of these factors. Hence, the degree of in vivo interaction between an enzyme and a substrate can be estimated using the [I] $\mathrm{u} / \mathrm{Ki}$ ratio, where [I] $\mathrm{u}$ refers to the concentration of the unbound drug and $\mathrm{Ki}$ is the in vitro inhibition constant for this enzyme [39]. Using $\mathrm{Ki}$ values of $68 \mathrm{nM}$ and $35 \mathrm{nM}$ for S-fluoxetine and S-norfluoxetine, Sager et al. reported a [I]u/Ki ratio of 5.8 for S-fluoxetine and of 4.5 for S-norfluoxetine (calculated using the unbound concentration in the liver), suggesting that the unbound concentration of these drugs at steady-state is much higher than the concentration required to block $50 \%$ of the CYP2D6 active site [39]. This concept can also be appreciated through the consideration of in vivo metabolic inhibition potential using pharmacokinetic parameters. Since the CYP2D6-mediated demethylation of fluoxetine to norfluoxetine is stereoselective, a more precise estimation is obtained by looking at S-enantiomer concentrations. Sager et al. studied the plasma levels of fluoxetine enantiomers following the administration of fluoxetine $60 \mathrm{mg}$ for 12 days to healthy volunteers; the average plasma concentration of S-fluoxetine and S-norfluoxetine was $770 \pm 270 \mathrm{nM}$ and $320 \pm 110 \mathrm{nM}$ (mean $\pm \mathrm{SD}$ ), respectively [39]. The plasma fraction unbound (fu) was estimated at 0.14 and 0.13 for S-fluoxetine and S-norfluoxetine, respectively. Based on these parameters, the predicted unbound plasma concentrations of S-fluoxetine (108 nM) and S-norfluoxetine $(42 \mathrm{nM})$ are within the range of CYP2D6 Ki values reported in different studies for S-fluoxetine (68-220 nM) and for S-norfluoxetine (35-310 nM). In these estimations, the average steady-state plasma concentrations instead of the maximal concentration were used to assess the potential metabolic inhibition of CYP2D6. The use of [I]u plasma/Ki can underestimate the prediction of in vivo drug interactions compared to the use of [I]in, $u$ liver/Ki ([I]in, u being the maximal unbound hepatic inlet concentration) [54]. In brief, the 
long-lasting CYP2D6 competitive inhibition by S-fluoxetine and S-norfluoxetine could be explained by their unbound concentrations remaining much higher than their Ki value throughout a dosing interval and days thereafter.

\section{CYP2C19 and Fluoxetine}

Fluoxetine is a substrate $(\mathrm{Km}=251 \mu \mathrm{M}$ and $154 \mu \mathrm{M}$; Clint $=0.186 \mathrm{uL} / \mathrm{min} / \mathrm{pmol}$ of CYP and $0.275 \mathrm{uL} / \mathrm{min} / \mathrm{pmol}$ of CYP for the S- and R-enantiomers, respectively) and a mechanism-based inhibitor of CYP2C19, as CYP2C19 is marginally involved in metabolizing fluoxetine into norfluoxetine [34,48]. In addition to the $N$-demethylation pathway, fluoxetine and possibly norfluoxetine undergo CYP2C19-mediated O-dealkylation to form the $p$-trifluoromethylphenol metabolite [33,35]. A 30-min fluoxetine pre-incubation shows a time-dependent reduction in CYP2C19 activity in vitro [55]. Additionally, Stresser et al. suggested stereoselective inhibition demonstrating that S-fluoxetine is a more potent mechanism-based inhibitor of CYP2C19 than the R-enantiomer (the S-enantiomer exhibited a lower affinity for the inactivation for CYP2C19 but a faster rate of inactivation compared to the R-fluoxetine) [55]. In contrast, Sager et al. assessed the risk of the irreversible inhibition of CYP2C19, and based on their in vitro ratios, they found that R-fluoxetine and S-norfluoxetine were most likely contributing to the irreversible inhibition of CYP2C19 [39]. In agreement with this study, in vitro time-dependent prediction models suggested that in pooled human liver microsomes, the inhibition of CYP2C19 was similar with racemicfluoxetine or racemic-norfluoxetine. When each enantiomer was considered independently, S-norfluoxetine was predicted to contribute the most to CYP2C19 inhibition [56]. Findings have been inconsistent; discrepancies between in vitro inhibition studies may be explained by enzyme sources, range of concentrations, and the in vitro models used. Overall, fluoxetine and norfluoxetine are likely to be perpetrator drugs for other CYP2C19 substrates. In support of this statement, the in vivo phase I clinical studies have shown reduced formation of the clopidogrel active metabolite (mediated largely by CYP2C19) and increased platelet aggregation when fluoxetine was co-administered with clopidogrel [57]. However, a study by Bykov et al. could not demonstrate a significant clinical impact on bleeding events [58].

\section{CYP2C9 and Fluoxetine}

In vitro studies suggest an important role for CYP2C9 in the metabolism of fluoxetine with stereoselectivity toward the R-enantiomer [37,46]. Pharmacogenetic studies evaluating fluoxetine transformation by microsomes from individuals with variant alleles coding for non- or decreased functional CYP2C9 activity suggested that fluoxetine is a substrate of CYP2C9 [36,59]. However, the affinity of fluoxetine toward CYP2C9 appears relatively low (Km value $=1660 \mu \mathrm{M}$ and $922 \mu \mathrm{M}$ for the S- and R-enantiomers, respectively), suggesting that it would likely be a victim drug if a stronger CYP2C9 substrates or inhibitors were co-administered [46]. In vivo, CYP2C9 seems to play a very minor role in the pharmacokinetics of fluoxetine [47]. These findings suggest that significant clinical drug interactions are unlikely through this pathway. There is no information available supporting the involvement of CYP2C9 in the sequential metabolism of norfluoxetine.

\section{CYP3A4 and Fluoxetine}

In vitro experiments have suggested a role for CYP3A4 in the metabolism of fluoxetine ( $\mathrm{Km}$ value $33.5 \mu \mathrm{M}$; Clint $=0.316 \mathrm{uL} / \mathrm{min} / \mathrm{pmol}$ of CYP) [37]. Furthermore, S-fluoxetine and R-norfluoxetine are reported to show some degree of mechanism-based inhibition towards CYP3A4 [56,60]. Through the use of pharmacokinetic-pharmacodynamic modeling, it has been predicted that a $60-62 \%$ reduction is possible in CYP3A4 activity when all enantiomers of parent drug and active metabolite are considered [60]. However, in vivo pharmacokinetic interaction studies with CYP3A4 sensitive substrates such as midazolam did not demonstrate the significant modification in midazolam pharmacokinetics as expected from in vitro studies [61]. In addition to a potential contribution to the $\mathrm{N}$ - 
demethylation pathway, in vitro studies suggested that CYP3A4 could contribute to the $O$-dealkylation of fluoxetine and perhaps norfluoxetine $[33,35]$. Based on in vitro studies, under conditions of nonfunctional CYP2C19 activity, it could be speculated that the impact of CYP3A4 on fluoxetine $O$-dealkylation can be revealed; however, the incongruity between in vivo and in vitro evidence will require further studies to provide any definitive conclusions.

\section{Conclusions}

Based on the information presented above, the strong CYP2D6 binding affinity of both S-fluoxetine and S-norfluoxetine, their unbound steady-state plasma concentrations above their respective Ki values, and their long elimination half-life all contribute to the prolonged inhibitory effects of fluoxetine and norfluoxetine on CYP2D6 activity. The mechanism of CYP2D6 inhibition by fluoxetine and norfluoxetine appears to be principally explained by competitive reversible inhibition. Clinically, separating the time of administration between fluoxetine and other CYP2D6 substrates will not be effective in mitigating DDIs, and the dose reduction of sensitive CYP2D6 substrates co-administered with fluoxetine is warranted to avoid adverse drug events.

Author Contributions: Conceptualization, J.T. and V.M.; methodology, M.D., S.B.A.R., V.M. and J.T.; formal analysis, V.M., M.D., S.B.A.R. and J.T.; writing—original draft preparation, V.M., M.D. and J.T.; writing-review and editing, J.T., V.M., S.B.A.R. and L.D.; visualization, M.D.; supervision, V.M. All authors have read and agreed to the published version of the manuscript.

Funding: This research received no external funding.

Institutional Review Board Statement: Not applicable.

Informed Consent Statement: Not applicable.

Data Availability Statement: Not applicable.

Acknowledgments: The authors would like to thank Pamela Dow for her support and Dana Filippoli for her comments pertaining to the contents of this manuscript.

Conflicts of Interest: All authors performed this work as employees (with stock options and shares) of Tabula Rasa HealthCare (f/k/a CareKinesis). The authors have no personal conflict of interest to disclose. The funder (TRHC board of directors) had no role in the design of the collection, analyses, or interpretation of data; in the writing of the manuscript; or in the decision to publish the results.

\section{References}

1. Rushton, C.A.; Strömberg, A.; Jaarsma, T.; Kadam, U.T. Multidrug and optimal heart failure therapy prescribing in older general practice populations: A clinical data linkage study. BMJ Open 2014, 4, e003698. [CrossRef] [PubMed]

2. Khan, A.; Preskorn, S. Multiple Medication Use in General Practice and Psychiatry: So What? Psychiatr. Times 2005, $22,8$.

3. Miccoli, R.; Penno, G.; del Prato, S. Multidrug Treatment of Type 2 Diabetes. Diabetes Care 2011, 34 (Suppl. 2), S231-S235. [CrossRef] [PubMed]

4. Wilsdon, T.D.; Hill, C.L. Managing the drug treatment of rheumatoid arthritis. Aust. Prescr. 2017, 40, 51-58. [CrossRef] [PubMed]

5. Courlet, P.; Livio, F.; Guidi, M.; Cavassini, M.; Battegay, M.; Stoeckle, M.; Buclin, T.; Alves Saldanha, S.; Csajka, C.; Marzolini, C.; et al. Polypharmacy, Drug-Drug Interactions, and Inappropriate Drugs: New Challenges in the Aging Population With HIV. Open Forum Infect. Dis. 2019, 6. [CrossRef]

6. Al-Musawe, L.; Torre, C.; Guerreiro, J.P.; Rodrigues, A.T.; Raposo, J.F.; Mota-Filipe, H.; Martins, A.P. Polypharmacy, potentially serious clinically relevant drug-drug interactions, and inappropriate medicines in elderly people with type 2 diabetes and their impact on quality of life. Pharmacol. Res. Perspect. 2020, 8, e00621. [CrossRef] [PubMed]

7. Khandeparkar, A.; Rataboli, P.V. A study of harmful drug-drug interactions due to polypharmacy in hospitalized patients in Goa Medical College. Perspect. Clin. Res. 2017, 8, 180-186. [CrossRef] [PubMed]

8. Nachega, J.B.; Hsu, A.J.; Uthman, O.A.; Spinewine, A.; Pham, P.A. Antiretroviral therapy adherence and drug-drug interactions in the aging HIV population. AIDS 2012, 26 (Suppl. 1), S39-S53. [CrossRef]

9. Campbell, N.L.; Dexter, P.; Perkins, A.J.; Gao, S.; Li, L.; Skaar, T.C.; Frame, A.; Hendrie, H.C.; Callahan, C.M.; Boustani, M.A. Medication adherence and tolerability of Alzheimer's disease medications: Study protocol for a randomized controlled trial. Trials 2013, 14, 125. [CrossRef]

10. McDonnell, A.M.; Dang, C.H. Basic review of the cytochrome p450 system. J. Adv. Pract. Oncol. 2013, 4, 263-268. [CrossRef] 
11. Estabrook, R.W. A passion for P450s (rememberances of the early history of research on cytochrome P450). Drug Metab. Dispos. 2003, 31, 1461-1473. [CrossRef] [PubMed]

12. Guengerich, F.P. Cytochrome p450 and chemical toxicology. Chem. Res. Toxicol. 2008, 21, 70-83. [CrossRef] [PubMed]

13. Weinberger, A.H.; Gbedemah, M.; Martinez, A.M.; Nash, D.; Galea, S.; Goodwin, R.D. Trends in depression prevalence in the USA from 2005 to 2015: Widening disparities in vulnerable groups. Psychol. Med. 2018, 48, 1308-1315. [CrossRef] [PubMed]

14. Mojtabai, R.; Olfson, M.; Han, B. National Trends in the Prevalence and Treatment of Depression in Adolescents and Young Adults. Pediatrics 2016, 138, 6. [CrossRef]

15. Case, A.; Deaton, A. Rising morbidity and mortality in midlife among white non-Hispanic Americans in the 21st century. Proc. Natl. Acad. Sci. USA 2015, 112, 15078-15083. [CrossRef] [PubMed]

16. Brody, D.J.; Gu, Q. Antidepressant Use Among Adults: United States, 2015-2018. Hyattsville, 2020. Available online: https: //www.cdc.gov/nchs/data/databriefs/db377-H.pdf (accessed on 23 November 2020).

17. Kane, S. Fluoxetine Hydrochloride, ClinCalc DrugStats Database, Version 21.0. Available online: https://clincalc.com/DrugStats / Drugs/FluoxetineHydrochloride (accessed on 23 November 2020).

18. Prozac (Fluoxetine Capsules), US Food and Drug Administration. Revised 2017. 1987. Available online: https:/ /www.accessdata. fda.gov/drugsatfda_docs/label/2017/018936s1081bl.pdf. (accessed on 23 November 2020).

19. Wong, D.T.; Perry, K.W.; Bymaster, F.P. Case history: The discovery of fluoxetine hydrochloride (Prozac). Nat. Rev. Drug Discov. 2005, 4, 764-774. [CrossRef]

20. Pigott, T.A.; Seay, S.M. A review of the efficacy of selective serotonin reuptake inhibitors in obsessive-compulsive disorder. J. Clin. Psychiatry 1999, 60, 101-106. [CrossRef]

21. Wong, D.T.; Bymaster, F.P.; Engleman, E.A. Prozac (fluoxetine, lilly 110140), the first selective serotonin uptake inhibitor and an antidepressant drug: Twenty years since its first publication. Life Sci. 1995, 57, 411-441. [CrossRef]

22. Mandrioli, R.; Forti, G.C.; Raggi, M.A. Fluoxetine metabolism and pharmacological interactions: The role of cytochrome p450. Curr. Drug Metab. 2006, 7, 127-133. [CrossRef]

23. Dean, L. Amitriptyline Therapy and CYP2D6 and CYP2C19 Genotype; Pratt, V.M., McLeod, H.L., Rubinstein, W.S., Scott, S.A., Dean, L.C., Kattman, B.L., Malheiro, A.J., Eds.; National Center for Biotechnology Information: Bethesd, MD, USA, 2012.

24. Smith, H.S. Opioid metabolism. Mayo Clin. Proc. 2009, 84, 613-624. [CrossRef]

25. Jazwinska-Tarnawska, E.; Orzechowska-Juzwenko, K.; Niewinski, P.; Rzemislawska, Z.; Loboz-Grudzien, K.; Dmochowska-Perz, M.; Slawin, J. The influence of CYP2D6 polymorphism on the antiarrhythmic efficacy of propafenone in patients with paroxysmal atrial fibrillation during 3 months propafenone prophylactic treatment. Int. J. Clin. Pharmacol. Ther. 2001, 39, 288-292. [CrossRef] [PubMed]

26. Amchin, J.; Ereshefsky, L.; Zarycranski, W.; Taylor, K.; Albano, D.; Klockowski, P.M. Effect of venlafaxine versus fluoxetine on metabolism of dextromethorphan, a CYP2D6 probe. J. Clin. Pharmacol. 2001, 41, 443-451. [CrossRef] [PubMed]

27. Liston, H.L.; DeVane, C.L.; Boulton, D.W.; Risch, S.C.; Markowitz, J.S.; Goldman, J. Differential time course of cytochrome P450 2D6 enzyme inhibition by fluoxetine, sertraline, and paroxetine in healthy volunteers. J. Clin. Psychopharmacol. 2002, 22, 169-173. [CrossRef] [PubMed]

28. Deodhar, M.; Al Rihani, S.B.; Arwood, M.J.; Darakjian, L.; Dow, P.; Turgeon, J.; Michaud, V. Mechanisms of CYP450 Inhibition: Understanding Drug-Drug Interactions Due to Mechanism-Based Inhibition in Clinical Practice. Pharmaceutics 2020, $12,846$. [CrossRef] [PubMed]

29. Shou, M.; Lin, Y.; Lu, P.; Tang, C.; Mei, Q.; Cui, D.; Tang, W.; Ngui, J.S.; Lin, C.C.; Singh, R.; et al. Enzyme kinetics of cytochrome P450-mediated reactions. Curr. Drug Metab. 2001, 2, 17-36. [CrossRef]

30. Kalgutkar, A.S.; Obach, R.S.; Maurer, T.S. Mechanism-based inactivation of cytochrome P450 enzymes: Chemical mechanisms, structure-activity relationships and relationship to clinical drug-drug interactions and idiosyncratic adverse drug reactions. Curr. Drug Metab. 2007, 8, 407-447. [CrossRef]

31. Fontana, E.; Dansette, P.M.; Poli, S.M. Cytochrome p450 enzymes mechanism based inhibitors: Common sub-structures and reactivity. Curr. Drug Metab. 2005, 6, 413-454. [CrossRef]

32. Benfield, P.; Heel, R.C.; Lewis, S.P. Fluoxetine. A review of its pharmacodynamic and pharmacokinetic properties, and therapeutic efficacy in depressive illness. Drugs 1986, 32, 481-508. [CrossRef]

33. Liu, Z.-Q.; Tan, Z.-R.; Wang, D.; Huang, S.-L.; Wang, L.-S.; Zhou, H.-H. Simultaneous determination of fluoxetine and its metabolite p-trifluoromethylphenol in human liver microsomes using a gas chromatographic-electron-capture detection procedure. $J$. Chromatogr. B 2002, 769, 305-311. [CrossRef]

34. Liu, Z.-Q.; Zhu, B.; Tan, Y.F.; Tan, Z.R.; Wang, L.S.; Huang, S.L.; Shu, Y.; Zhou, H.H. O-Dealkylation of fluoxetine in relation to CYP2C19 gene dose and involvement of CYP3A4 in human liver microsomes. J. Pharmacol. Exp. Ther. 2002, 300, 105-111. [CrossRef]

35. Urichuk, L.J.; Aspeslet, L.J.; Holt, A.; Silverstone, P.H.; Coutts, R.T.; Baker, G.B. Determination of p-trifluoromethylphenol, a metabolite of fluoxetine, in tissues and body fluids using an electron-capture gas chromatographic procedure. J. Chromatogr. B. Biomed. Sci. Appl. 1997, 698, 103-109. [CrossRef]

36. Lerena, A.L.; Dorado, P.; Berecz, R.; González, A.P.; Ledó, E.M.P. Effect of CYP2D6 and CYP2C9 genotypes on fluoxetine and norfluoxetine plasma concentrations during steady-state conditions. Eur. J. Clin. Pharmacol. 2004, 59, 869-873. [CrossRef] 
37. Margolis, J.M.; Donnell, J.P.; Mankowski, D.C.; Ekins, S.; Obach, R.S. (R)-, (S)-, and Racemic Fluoxetine N-Demethylation by Human Cytochrome P450 Enzymes. Drug Metab. Dispos. 2000, 28, 1187-1191.

38. Fjordside, L.; Jeppesen, U.; Eap, C.B.; Powell, K.; Baumann, P.; Brossen, K. The stereoselective metabolism of fluoxetine in poor and extensive metabolizers of sparteine. Pharmacogenet. Genom. 1999, 9. [CrossRef] [PubMed]

39. Sager, J.E.; Lutz, J.D.; Foti, R.S.; Davis, C.; Kunze, K.L.; Isoherranen, N. Fluoxetine- and norfluoxetine-mediated complex drug-drug interactions: In vitro to in vivo correlation of effects on CYP2D6, CYP2C19, and CYP3A4. Clin. Pharmacol. Ther. 2014, 95, 653-662. [CrossRef]

40. Alfaro, C.L.; Lam, Y.W.F.; Simpson, J.; Ereshefsky, L. CYP2D6 Inhibition by Fluoxetine, Paroxetine, Sertraline, and Venlafaxine in a Crossover Study: Intraindividual Variability and Plasma Concentration Correlations. J. Clin. Pharmacol. 2000, 40, 58-66. [CrossRef]

41. Greenblatt, D.J.; Zhao, Y.; Venkatakrishnan, K.; Duan, S.X.; Harmatz, J.S.; Parent, S.J.; Court, M.H.; von Moltke, L.L. Mechanism of cytochrome P450-3A inhibition by ketoconazole. J. Pharm. Pharmacol. 2011, 63, 214-221. [CrossRef]

42. Stevens, J.C.; Wrighton, S.A. Interaction of the enantiomers of fluoxetine and norfluoxetine with human liver cytochromes P450. J. Pharmacol. Exp. Ther. 1993, 266, 964-971.

43. Bertelsen, K.M.; Venkatakrishnan, K.; von Moltke, L.L.; Obach, R.S.; Greenblatt, D.J. Apparent mechanism-based inhibition of human CYP2D6 in vitro by paroxetine: Comparison with fluoxetine and quinidine. Drug Metab. Dispos. 2003, 31, 289-293. [CrossRef]

44. Bertilsson, L.; Dahl, M.-L.; Dalén, P.; Al-Shurbaji, A. Molecular genetics of CYP2D6: Clinical relevance with focus on psychotropic drugs. Br. J. Clin. Pharmacol. 2002, 53, 111-122. [CrossRef]

45. Scordo, M.G.; Spina, E.; Dahl, M.-L.; Gatti, G.; Perucca, E. Influence of CYP2C9, 2C19 and 2D6 genetic polymorphisms on the steady-state plasma concentrations of the enantiomers of fluoxetine and norfluoxetine. Basic Clin. Pharmacol. Toxicol. 2005, 97, 296-301. [CrossRef] [PubMed]

46. Wang, Z.; Wang, S.; Huang, M.; Hu, H.; Yu, L.; Zeng, S. Characterizing the Effect of Cytochrome P450 (CYP) 2C8, CYP2C9, and CYP2D6 Genetic Polymorphisms on Stereoselective N-demethylation of Fluoxetine. Chirality 2014, 26, 166-173. [CrossRef] [PubMed]

47. Gassó, P.; Rodríguez, N.; Mas, S.; Pagerols, M.; Blázquez, A.; Plana, M.T.; Torra, M.; Lázaro, L.; Lafuente, A. Effect of CYP2D6, CYP2C9 and ABCB1 genotypes on fluoxetine plasma concentrations and clinical improvement in children and adolescent patients. Pharmacogenomics J. 2014, 14, 457-462. [CrossRef] [PubMed]

48. Eap, C.B.; Bondolfi, G.; Zullino, D.; Savary-Cosendai, L.; Powell-Golay, K.; Kosel, M.; Baumann, P. Concentrations of the Enantiomers of Fluoxetine and Norfluoxetine After Multiple Doses of Fluoxetine in Cytochrome P4502D6 Poor and Extensive Metabolizers. J. Clin. Psychopharmacol. 2001, 21, 330-334. [CrossRef]

49. Zajecka, J.; Fawcett, J.; Amsterdam, J.; Quitkin, F.; Reimherr, F.; Rosenbaum, J.; Michelson, D.; Beasley, C. Safety of Abrupt Discontinuation of Fluoxetine: A Randomized, Placebo-Controlled Study. J. Clin. Psychopharmacol. 1998, 18, 193-197. [CrossRef] [PubMed]

50. Bogetto, F.; Bellino, S.; Revello, R.B.; Patria, L. Discontinuation syndrome in dysthymic patients treated with selective serotonin reuptake inhibitors: A clinical investigation. CNS Drugs 2002, 16, 273-283. [CrossRef]

51. Hicks, J.K.; Swen, J.J.; Thorn, C.F.; Sangkuhl, K.; Kharasch, E.D.; Ellingrod, V.L.; Skaar, T.C.; Müller, D.J.; Gaedigk, A.; Stingl, J.C. Clinical Pharmacogenetics Implementation Consortium guideline for CYP2D6 and CYP2C19 genotypes and dosing of tricyclic antidepressants. Clin. Pharmacol. Ther. 2013, 93, 402-408. [CrossRef]

52. Preskorn, S.H.; Alderman, J.; Chung, M.; Harrison, W.; Messig, M.; Harris, S. Pharmacokinetics of desipramine coadministered with sertraline or fluoxetine. J. Clin. Psychopharmacol. 1994, 14, 90-98. [CrossRef]

53. Pato, M.T.; Murphy, D.L.; Devane, L.C.P. Sustained Plasma Concentrations of Fluoxetine and/or Norfluoxetine Four and Eight Weeks After Fluoxetine Discontinuation. J. Clin. Psychopharmacol. 1991, 11, 224-225. [CrossRef]

54. Iwasaki, S.; Hirabayashi, H.; Amano, N. Quantitative prediction of the extent of drug-drug interaction using a physiologically based pharmacokinetic model that includes inhibition of drug metabolism determined in cryopreserved hepatocytes. Xenobiotica 2018, 48, 770-780. [CrossRef]

55. Stresser, D.; Mason, A.; Perloff, E.; Ho, T.; Crespi, C.; Dandeneau, A.; Morgan, L.; Dehal, S. Differential Time- and NADPHdependent Inhibition of CYP2C19 by Enantiomers of Fluoxetine. Drug Metab. Dispos. 2009, 37, 695-698. [CrossRef] [PubMed]

56. Ring, B.J.; Eckstein, J.A.; Gillespie, J.S.; Binkley, S.N.; VandenBranden, M.; Wrighton, S.A. Identification of the human cytochromes p450 responsible for in vitro formation of R- and S-norfluoxetine. J. Pharmacol. Exp. Ther. 2001, 297, 1044-1050. [PubMed]

57. Delavenne, X.; Magnin, M.; Basset, T.; Piot, M.; Mallouk, N.; Ressnikoff, D.; Garcin, A.; Laporte, S.; Garnier, P.; Mismetti, P. Investigation of drug-drug interactions between clopidogrel and fluoxetine. Fundam. Clin. Pharmacol. 2013, 27, 683-689. [CrossRef] [PubMed]

58. Bykov, K.; Schneeweiss, S.; Donneyong, M.M.; Dong, Y.-H.; Choudhry, N.K.; Gagne, J.J. Impact of an Interaction Between Clopidogrel and Selective Serotonin Reuptake Inhibitors. Am. J. Cardiol. 2017, 119, 651-657. [CrossRef]

59. Schmider, J.; Greenblatt, D.J.; von Moltke, L.L.; Karsov, D.; Shader, R.I. Inhibition of CYP2C9 by selective serotonin reuptake inhibitors in vitro: Studies of phenytoin p-hydroxylation. Br. J. Clin. Pharmacol. 1997, 44, 495-498. [CrossRef] 
60. Lutz, J.D.; VandenBrink, B.M.; Babu, K.N.; Nelson, W.L.; Kunze, K.L.; Isoherranen, N. Stereoselective inhibition of CYP2C19 and CYP3A4 by fluoxetine and its metabolite: Implications for risk assessment of multiple time-dependent inhibitor systems. Drug Metab. Dispos. 2013, 41, 2056-2065. [CrossRef]

61. Lam, Y.W.F.; Alfaro, C.L.; Ereshefsky, L.; Miller, M. Pharmacokinetic and pharmacodynamic interactions of oral midazolam with ketoconazole, fluoxetine, fluvoxamine, and nefazodone. J. Clin. Pharmacol. 2003, 43, 1274-1282. [CrossRef] 